\title{
Instruments of International Commercial Contract
}

\section{Suman Acharya, PhD}

Email: sumanacharaya@gmail.com

\begin{abstract}
There has been a growing role of international commercial contract along with the globalization and transnationalization of trade. As international contract covers all issues of trade, international sales of contract is a popular one. While concluding commercial contract, country specific law having jurisdiction and substantial provisions cannot be forgotten. The contract cannot be concluded squashing universally accepted principles and competition policy which are established by peremptory norms. Any covert intention to remove competition policy is starkly declined in the contract provision. The damage can be claimed in court of law having jurisdictions as contracted if anything is unhealthy and unreasonable. International instruments i.e. treaty or recommendations want to establish uniform rules of practices across the globe in the matter of international commercial contracts, which are binding to member country.
\end{abstract}

\section{Introduction}

International commercial contract has been concluded for cross border transactions, which consists of offer; contract; shipment; acceptance of delivery; warranty period; and final payment etc. ${ }^{1}$ So, international financing method, arbitration, sales of goods contract etc. must adopt the principle of contract which are almost universally accepted. The use of international commercial contract has been increasing and ever increasing. The jurisdiction for the prosecution under international commercial contract is as designated under contract provisions. But, it must not violate national law provision for the

1 Vide Anders Grath. The Handbook of International Trade and Finance. 76 (2008). Kogan Page: London. 
enforceability if it has domestic nature. Earlier international commercial contract was scattered and random in nature. It has been in the process of unification and harmonization by the world community in recent time. This area of contract has been flourished with the growth of transnational trade. Preamble of UNIDROIT Principles (2016) accepts international contract as "significant connection with more than one state", "involving a choice between the laws of different States", or "affecting the interests of international trade" etc. ${ }^{2}$

\section{Types of International Commercial Contract}

International commercial contract covers wide ranges of activities i.e. production, distribution, exchange and consumption etc. Merchandising goods, service, intellectual property, market research, payment methods etc all are included under international commercial contract. Generally, it follows standard form of contract with little customization so that uniformity in business transaction may be possible. It includes short term sales contract and long term manufacturing contract. Merchant contract is more relevant than consumer transactions to refer international commercial contract.

- International Manufacturing Contract: It can cover complete development of product or assembling the parts produced in various countries. It can cover franchising or licensing, importing and exporting, fully established Joint Venture Company, local branches, strategic alliances etc. 'Licences of technology need to be drafted in the light of the laws of Contract, Intellectual Property, E-Commerce and Competition. 3

- International Sales of Contract: It is the contract occurred between buyer and seller in transnational business. It identifies buyer, seller, quantity, price, payment method and many more.

2 Principles of International Commercial Contracts $§$ Preamble. (2016).

https://www.unidroit.org/instruments/commercial-contracts/unidroit-principles-2016. (Last Visited on 4/20/2020).

3 Rebecca Attree. A Specially Commissioned Report; International Commercial Agreements. 214 (2002).

Thorogood. 
- International Distribution Contract: This sort of contract covers the relation between producer, wholesaler, and retailer. It links different chain of distribution of goods.

- International Agency Contract: Foreign Company can designate agency regionally or locally so that the promotion of trade or business is possible. A person getting agency from foreign company works on behalf of it based on terms of references.

- International Service Contract: It covers the issue of supply of service from one company to another. It can be both domestic and international.

\section{Instruments of International Sales of Contract}

Every contract has to be concluded in such a way that prior similar contracts are superseded. A person who has not exercised rights or remedy doesn't construe that the person made waiver of the provision. Yet, no oral amendment is possible in contractual provision. Similarly, if some part of the contract is illegal, only this provision will be ineffective under doctrine of severability and breach of fundamental issue makes contract ineffective. The sole remedy goes to buyer if it doesn't get delivery in time and without final conclusion, no contract can be taken place. Strict application of such terminology may be disadvantages to another party, which needs pliable interpretation. Lawyers of both sides try to negotiate each other focusing on their consideration. ${ }^{4}$ Some of the international instruments of sales of goods contract are as under.

- The International Institute for the Unification of Private Law (1994, 2004, 2010, 2016): It issued Principles of International Commercial Contracts (2016), which is most recent principles of international commercial contract. It has been updating commercial contract principles in regular interval of time. A contract may be concluded either by the acceptance of an offer or by conduct of the parties

Vide Giuditta Cordero-Moss (ED). International Commercial Contracts and the Applicable Laws. 50

(2011). Cambridge University Press: New York. 
that is sufficient to show agreement, ${ }^{5}$ a proposal for concluding a contract constitutes an offer if it is sufficiently definite and indicates the intention of the offeror to be bound in case of acceptance, ${ }^{6}$ an offer becomes effective when it reaches the offeree and an offer, even if it is irrevocable, may be withdrawn if the withdrawal reaches the offeree before or at the same time as the offer, ${ }^{7}$ and many more principles are included by it. ${ }^{8}$

- The United Nations Convention on Contracts for the International Sale of Goods (1980): It is applicable in the contracts of sale of goods between States and in the area applicable of rules of private international law. However, this doesn't apply to the goods bought by person, family, household, stocks, share, electricity or aircraft or ship etc. It covers product, quantity, delivery, price, payment terms, transfer of ownership, insurance, government requirement, dispute resolution, and applicable laws etc. ${ }^{9}$

- The Hague Convention on the Law Applicable to Contracts for International Sale of Goods (1986): Under the Convention, goods include ships, vessels, boats, hovercraft and aircraft and electricity. It is applicable for the sale between parties having their places of business in different States and their choice of laws as stipulated by the party. ${ }^{10}$

- Convention on the Limitation Period in the International Sale of Goods (1974): It is the part of the United Nations Convention on Contracts for the

Id. $\S$ Art. 2.1.1.

Id. $\S$ Art. 2.1.2.

Id. § Art. 2.1.3.

Vide Principles of International Commercial Contracts $\S(2016)$ https://www.unidroit.org/instruments/commercial-contracts/unidroit-principles-2016. (Last Visited on 4/20/2020).

United Nations Convention on Contracts for the International Sale of Goods $\S$ Art. 2 (1980). https://www.uncitral.org/pdf/english/texts/sales/cisg/V1056997-CISG-e-book.pdf. (Last Visited on 4/20.2020). This Convention does not apply to sales: (a) of goods bought for personal, family or household use, unless the seller, at any time before or at the conclusion of the contract, neither knew nor ought to have known that the goods were bought for any such use; (b) by auction; (c) on execution or otherwise by authority of law; (d) of stocks, shares, investment securities, negotiable instruments or money; (e) of ships, vessels, hovercraft or aircraft; (f) of electricity. It came into force as a multilateral treaty on 1 January 1988. Convention on the Law Applicable to Contracts for the International Sale of Goods § (1986).

https://assets.hcch.net/docs/b4698bc5-9d42-4352-934f-5232a8dcb12c.pdf. (Last Visited on 4/20/2020). 
International Sale of Goods, 1980 which covers the issue of limitation occurred through passage of time. It covers the non-applicability of the claim of buyer and seller because of special situations. ${ }^{11}$ It applies only to the places of business of the parties in terms of the international sales of goods and the rules of private international law if parties make this provision. If it is expressly excluded, it is not applicable. ${ }^{12}$ It doesn't apply to the sales for the goods brought for household purpose, auction, execution, stock, share investment, ship, vessel, aircraft, and electricity. ${ }^{13}$ It is not applicable for labor supply as well.

- Uniform Rules on Contract Clauses for an Agreed Sum Due upon Failure of Performance (1983): It seeks to unify the legal treatment for the payment of specified sum of money as damages or penalty for the failure of the party to perform contractual obligations. ${ }^{14}$ These Rules apply to international contracts in which the parties have agreed but failed to perform. It carries compensation or penalty from one party to another. ${ }^{15}$

\section{- UNCITRAL Legal Guide on International Countertrade Transactions} (1992): It is the issue of payment from goods and service instead of money. Countertrade is contemporary practices in international sales of goods contract. There are different types of countertrade i.e. barter trade, compensation trade, buy

\footnotetext{
$11 \quad$ Convention on the Limitation Period in the International Sale of Goods § Art. 1 (1974). https://www.uncitral.org/pdf/english/texts/sales/limit/limit_conv_E Ebook.pdf. (Last Visited on 4/18/2020).

12 Id. § Art. 3.

13 Id. $\S$ Art. 4.

14 Uniform Rules on Contract Clauses for an Agreed Sum Due upon Failure of Performance $§$ (1983), https://uncitral.un.org/en/texts/salegoods/contractualtexts/failure of performance. (Last Visited on 4/18/2020).

15 Id. $\S$ Art.1. https://uncitral.un.org/sites/uncitral.un.org/files/media-documents/uncitral/en/vol14-p272-273e.pdf. (Last Visited on 4/18/2020).
} 
back, counter purchase, switch trading, offset purchase for raw material or finished product etc. ${ }^{16}$

\section{- The Convention on the Recognition and Enforcement of Foreign Arbitral} Awards (1958): There can be dispute even in commercial issues. Parties are free to choose pacific means of dispute resolution including arbitration. It has been applied globally to member country. The convention applicable for dispute resolution process, which supports enforcement of international arbitration. ${ }^{17}$ Arbitration law of Nepal recognizes it if it fulfills the condition mentioned in this law as well. ${ }^{18}$

UNCITRAL Legal Guide on International Countertrade Transactions § (1992). https://www.uncitral.org/pdf/english/texts/sales/countertrade/countertrade-e.pdf. (Last Visited on 4/18/2020).

Convention on the Recognition and Enforcement of Foreign Arbitral Awards $\S$ (New York, 1958). https://www.uncitral.org/pdf/english/texts/arbitration/NY-conv/New-York-Convention-E.pdf. (Last Visited on $4 / 18 / 2020)$.

Arbitration Act $\quad \S \quad$ Sec. $34 \quad$ (2055). $\quad$ https://cn.nepalembassy.gov.np/wpcontent/uploads/2017/11/arbitration-act-2055-1999.pdf. (Last Visited 6/2/2020). It reads as Implementation of award Taken in a Foreign Country: (1) A party which willing to implement an award made in foreign country in Nepal shall submit an application to the High Court along with the following documents: (a) The original or certified copy of the arbitrators award . (b) The original or certified copy of the agreement. (c) In case the arbitrators award is not in the Nepali Language, an official translation thereof in Nepali language. (2) In case Nepal is a party to any treaty which provides for recognition and implementation of decisions taken by arbitrators in foreign countries, any decision taken by an arbitrator after the commencement of this act within the area of the foreign country which is a party to that treaty shall be recognised and implemented in Nepal in the following circumstances subject to the provisions of that treaty and the conditions mentioned at the time of entering into the treaty . (a) In case the arbitrator has been appointed and award made according to the laws and procedure mentioned in the agreement. (b) In case the parties had been notified about the arbitration proceedings in time. (c) In case the decision has been taken according to the conditions mentioned in the agreement or upon confining only to the subject matters referred to the arbitrator. (d) In case the decision has become final and binding on the parties according to the laws of the country where the decision has been taken. (e) In case the laws of the country of the petitioner or the laws of the country where arbitration proceedings have been conducted, do not contain provision under which arbitration award taken in Nepal cannot be implemented. (f) In case the application has been filed for the implementation of the award within 90 days from the date of award. (3) In case the Appellate Court is satisfied that the conditions mentioned in Sub-section (2) have been fulfilled in the an application filed pursuant to Sub-section (1) it shall forward the award to the District court for its implementations. (4) Notwithstanding anything contained in this Section, no award made by an arbitrator in a foreign country shall be implemented in the following circumstances. (a) In case the awarded settled dispute cannot be settled through arbitration under the laws of Nepal. (b) In case the implementation of the award is detrimental to the public policy. 
- United Nations Convention on the Use of Electronic Communications in International Contracts (2005): It applies in the use of electronic communication between the parties involved different states. However, it is not applicable to contracts concluded by person, family or household or transaction on regulated exchanges like foreign exchange transaction, interbank payment system or bills of exchange, promissory notes, consignment notes, bills of lading, warehouse receipts or any transferable documents. ${ }^{19}$

\section{Incoterms (2020)}

International Commercial Terms (Incoterms) was first introduced in 1936 which has been updated since then. It is also published by International Chamber of Commerce. It closely corresponds with the U.N. Convention on Contracts for the International Sales of Goods. It has been amended in 1953, 1967, 1976, 1980, 2000, 2010 and 2020. ${ }^{20}$ Incoterms (2020) covers following area. ${ }^{21}$

\begin{tabular}{|c|c|}
\hline $\begin{array}{ll} & \text { Any mode of transport: } \\
\text { - } & \text { EXW - Ex Works } \\
\text { - } & \text { FCA - Free Carrier } \\
\text { - } & \text { CPT - Carriage Paid to } \\
\text { - } & \mathrm{CIP}-\text { Carriage and Insurance Paid to } \\
\text { - } & \text { DAP - Delivered at Place } \\
\text { - } & \text { DPU - Delivered at Place Unloaded } \\
\text { - } & \text { DDP - Delivered Duty Paid }\end{array}$ & $\begin{array}{l}\text { Sea and inland waterway transport: } \\
\text { - } \text { CFR - Cost and Freight } \\
\text { - FOB - Free On Board } \\
\text { - FAS - Free Alongside Ship } \\
\text { - } \text { CIF - Cost, Insurance and Freight }\end{array}$ \\
\hline
\end{tabular}

(Source: ICC)

19 United Nations Convention on the Use of Electronic Communications in International Contracts § (2005). https://www.uncitral.org/pdf/english/texts/electcom/06-57452_Ebook.pdf. (Last Visited on 4/18/2020).

\footnotetext{
20 The Beginner's Introduction to Incoterms. https://www.shippingsolutions.com/blog/beginners-introductionto-incoterms. (Last Visited on 4/18/2020).

$21 \quad$ Incoterms $\S(2020)$. https://www.tibagroup.com/blog/incoterms-2020?lang=es. (Last Visited on $4 / 18 / 2020)$.
} 


\section{Sales of Goods Contract in Nepal}

The contract between the party is as designated under the National Civil Code, 2017 AD (2074 BS) in Nepal. It has detail provisions on contract. Part five of the Code provides 'Provisions Relating to Contracts and Other Liabilities.' Chapter six of it provides for 'Provisions Relating to Contracts of Sales of Goods. ${ }^{22}$ If any seller agrees to transfer the goods immediately or in the future to the buyer, it will be sales of goods contract. It can be both conditional and unconditional. ${ }^{23}$ If the contract has been concluded for damaged product unknowingly, it will be void. ${ }^{24}$ Price can be determined under terms and conditions of the contract, and weight and measurement which should be reasonable in given circumstances. ${ }^{25}$ Mode of payment is as under contract provision or in the time of purchase or transfer. ${ }^{26}$ Description of goods like name, brand, quality, trademark and specifications are as prescribed in contract. ${ }^{27}$ Title and ownership will be transferred from seller to buyer once goods have been transferred or money is paid back. Prior than transfer, the loss or damage should be carried out by seller. ${ }^{28}$ If goods are bought in sample basis in bulk, sample standard should be fulfilled. ${ }^{29}$ It has also mentioned time of delivery of goods, documents required to handover, not to deliver of goods in quantity different from quantity specified in contract, non acceptance of different quantity, compensation and 2 years limitation for filing the case etc.

\section{Case Laws}

- Francis Travel Marketing Pty Ltd vs. Virgin Atlantic Airways Ltd: The arbitration clause of the contract cannot be construed narrowly. It has been

\footnotetext{
22 Vide National Civil Code $\S$ Chapter Six. Part Five . (2074). http://www.moljpa.gov.np/en/wpcontent/uploads/2018/12/Civil-code.pdf. (Last Visited on 4/20/2020).

Id. $\S$ Sec. 545.

Id. $\S$ Sec. 546 .

Id. $\S$ Sec. 547.

Id. $\S$ Sec. 548.

Id. $\S$ Sec. 549.

Id. $\S$ Sec. 555 .

Id. $\S$ Sec. 553 .
} 
unlikely intended that slightly different dispute can be settled through different tribunals. $^{30}$

- Courage ruling: ECJ, 20 September 2001, Case C-453/99: The claim of damages in court of law in case of loss caused by contract and other unreasonable policy strengthens competition law which cannot be argued for limiting the rights of it. Maintenance of effective competition in the market is essential. It discourages covert agreement harmful to competition law. ${ }^{31}$

- Williams vs. Walker-Thomas Furniture Co.: This case deals with the issue of unconscionability. The contract beyond the good conscience is not acceptable. There should be meaningful choice in case of unreasonably favorable to the other party. $^{32}$

- Antaios Compania SA vs. Salen Redeiera (1985) AC 191: As the provision of contract 'on any breach of this charterparty, the owners shall be at liberty to withdraw the vessel'. As the owner tries to bring a charter to an end on the ground of inaccurate bills of lading, House of Lords argues that it is uncommercial and unreasonable and conflicted with the whole purpose of the charter form because no contract can be interpreted to defeat the whole commercial purpose. ${ }^{33}$

\section{Conclusion}

International commercial contract is important part of international trade. Now, it has been in the process of unification and harmonization with the leadership of private and intergovernmental agencies across the globe. The jurisdiction of enforceability is the prime concern because it cannot violate substantial provision of contract law accepted by the country. In terms of international commercial contracts, there are binding and voluntary instruments. Treaty or Conventions are binding instruments for the member

(1996) 39 NSWLR 160 at 165 (CA), quoted in Anders Grath. The Handbook of International Trade and Finance. 737 (2008). Kogan Page: London.

31 Courage Ruling, paras. 26-28, Quoted in Giuditta Cordero-Moss (ED). International Commercial Contracts and the Applicable Laws. 109 (2011). Cambridge University Press:New York.

Williams v. Walker-Thomas Furniture. Co. 350 F.2d 445. 449 (D.C. Cir. 1965), quoted Id $\S 86$. Robert Ribeiro. A Specially Commissioned Report; Commercial Contract; Drafting Techniques and Precedents. 34-35 (2005). Thorogood. 
country whereas model laws are the voluntary in nature. In international trade law, there can be unequal provision to conclude contract law but it cannot violate universal principle of contract law. No exculpatory provision to remove competition is expected in the name of contractual agreement.

\section{'The End...'}

